\title{
Intuition as Part of Informatics Creativity
}

\author{
http://dx.doi.org/10.3991/ijep.v3i3.2521 \\ Walfredo González Hernández \\ Universidad de Matanzas, Matanzas, Cuba
}

\begin{abstract}
The development of creativity is necessary for all professionals and universities cannot be exempted from it. According to studies (Acentura, 2007) is one of creativity does not develop skills in universities. Important factors of creativity is the intuition study by many authors but is not a concluded investigation. This paper presents the characteristics of intuition as part of informatics creativity.
\end{abstract}

Index Terms-Informatics Teach, Creativity

\section{INTRODUCTION}

Creativity has been studied from antiquity to the present day (Gonzalez, 2004; Mitjáns, 1995, de la Torre, 2002) and many theoretical assumptions have been developed since then. All have agreed in recognizing the unity of intuition and logic in this process although each author has given prominence to one or the other. However, on intuitive processes there is a stalemate that has lasted several years (Sinclair, 2011). Various psychological currents have addressed the issue from different angles, highlighting in this article the three most important in this study: cognitivisto, humanism and historical approach - cultural.

Furthermore, the formation process engineer has been treated differently in the scientific literature (Gonzalez, 2004) but has not been treated to the creative process and especially the development of intuition. That is why this article is an approach to the study of intuition in computing and how to develop it in the process of training of engineers.

\section{DEVELOPMENT}

The development of man as a social being imposed on this certain challenges in the educational context. It is in the historical process where you can find that work has been the generator of the greatest discoveries. In the process of social historical development reaffirms man as a social being and evolves depending on their conditions. Their performance is explained by the relationship established between the subject and the society in which he expresses the relationship between the singular and the general. Men make history conditioned by the activity engaged in this activity and are the basis for the discovery of new knowledge and ways of action in relation to society and nature.

He agrees with Dr. Marta Martinez Wheeler (1995) when he says that the theoretical and practical assessment leading to the view that creativity is expressed in the transformative socio essence of man, which is not to say that all men are creators, but all can be potentially.

There are countless ways to develop it. Many authors among which we can highlight to David Prado (2003), Edward de Bono (1973), A. Mitjáns (1995, 1997, 2002), America Gonzalez Valdes $(1995,1999)$ work in this area and even have some conflicting criteria in all contact points are highlighted. One unit is the logical and intuitive. Based on their analysis one can conclude that agree on the importance of logic in the verification stage. It is possible the contrast between logic and intuition to be stages of the same process: the creation. Intuition presents new ways to solve known problems, streamlines the work but the ideas generated in the process should be filtered using intuitive as satellite operations and logical forms of thought.

The creative process is long and complex, and it plays an important role intuitive assumptions and carefully planned research. With intuition man can find solutions to their business problems, they may be wrong or not. So, intuitive solutions should be verified through logic. The linkage between the logical and the intuitive occurs throughout the creative process and in general human activity. It can be said that intuition has a strong foundation in the subject's experience in a particular field of activity.

This sudden intuition also appears in creative scientific work, sometimes hypothetical tasks whose solutions are easier than the methods or paths leading to it, ie when the result, the end point, which obviously must lead the thinking can anticipate Although the paths that could lead to it, are not yet sufficiently known. As is known these cases occur in science.

Psychoanalysis has addressed the issue preferably motivational creation, claiming that this is rooted in the unconscious conflicts and is an embodiment thereof through sublimation. L. Kubie (2001), points out the value of preconscious processes for human activity. Meanwhile E. Kris (1999) provided ideas regarding that creativity is a phase and another elaboration inspirations. In the first, is temporarily lost control of thought processes, allowing regression preconscious levels leading to greater receptivity to manage ideas and impulses unrelated.

With the onset of dual processing theories (Evans, 2007; Stanovich \& West, 2000; Dijksterhuis, 2004; Dijksterhuis \& Aarts, 2010), there has been a growing consensus That information is processed by two independent systems interact seamlessly That - until we consciously Intervene.

Significantly, the analysis of the conception from building products (Mintzberg, 1998; Sinclair \& Ashkanasy, 2005; Ponomariev, 2002). For this author at the time of rest at a subconscious level are produced free associations, based on the experience of the subject, which go through a decanting at this level. These associations are gathering and are forming a solution of the problem starts at the moment, to be felt by the individual as a feeling of wellbeing. Also interesting studies about the parts of the brain that are stimulated in intuitive processes (Volz and Cramon, 2006; KIRSTEN G. Volz, Rubsamen and YVES, 2008; Reimann \& Bechara, 2010). When this process is 
PAPER

INTUITION AS PART OF INFORMATICS CREATIVITY

finished and the individual believed to have "dictated" the solution of the problem. However, it is recognized that this process is not the same for everyone and shaped into different styles and the way it appears, recognizing the role of affect in the process intuitive (Dane \& Pratt, 2009; Dorl er, 2010; Sinclair , 2011; Slovic, Paul and Västfjäll, Daniel, 2010).

In this case seen by the author to the affective approach in the study of intuition which is insufficient for understanding and leaves several questions. However, it should be noted in the analysis of intuition by cognitivism, it is necessary to consider the free associations or divergent (Sinclair, 2011) but not offered the way down, the creative intuition as a style used in decision-making (Sinclair \& Ashkanasy, 2005; Blume, Brian D, Covin, Jeffrey G., 2011, Dane, E., \& Pratt, M. G, 2007; Morewedge and Kahneman, 2010; Sinclair and Ashkanasy , 2005; Martin and Hanlon, 2007; DANE and PRATT, 2007; Epstein, 2008; Betsch, 2008; Morewedge and Kahneman, 2010; formulated as the integral part of decision making) or problem solving rather than a function itself (Sinclair, 2011, Dane and Pratt's, 2009) which relates the intuition with troubleshooting. It agrees with Sinclair (2011:13) when he says "Intuitive expertise draws mostly on locally stored accumulated domain-specific patterns in the past". This statement relates to motivation intuition this being particularly important in the development process and formation of an expert in a particular area of knowledge, though the author does not explicitly refer.

On the other hand, cultural historical perspective emphasizes intuition as part of the thought processes intimately related affective processes. For Dr. Rita Roland (3) defines intuition from its development as a human capacity. For other Cuban scholars highlighted as part of the dialectical relationship established with logical thinking, vital for the development of creativity (A. Gonzalez, 1995; A. Minujin, 1988; A. Mitjáns, 1995, Gonzalez, 2004; Geisel, 2008; Oliveira, 2009). Although it appears that Vygotsky has been busy of intuition can peer into his work elements that could lead to explain the origin of free associations expressed above.

For Vygotsky (1934:50) in children may find the language that defines complex as follows: "The thinking is complex and coherent thought and purpose, but does not reflect the objective relations just as conceptual thinking", from which it follows that there are differences between the author called conceptual thinking. Subsequently, the author continues differentiating these concepts "... A complex, therefore, is first and foremost a given pool of objects connected by real links, and as there is formed in the plane of logical-abstract to junctions creates, as well as helping to create, lack logic unit and can be of many different types. Any truly present connection can lead to the inclusion of a given element in a complex. fundamental difference between a complex and consists concept following: while the latter groups objects according to one attribute, the links that connect the elements of a complex with the total, and each other, can be as diverse as they are actually the contacts and relationships of the elements. " (Vygotsky, 1934: 50). In this paragraph we can infer that there is great similarity between free associations or associations Ponomariev analyzed by divergent Sinclair (2011) and for complex thought addressed by Vygotsky.

Following Vygotsky's ideas concerning the complex thinking by this author classifies them into five types
(Vygotsky, 1934) in which we can appreciate the features addressed are linkages intuition as variables in the grouping of objects, contrast and similarity selection. Another similar device is in "... The critical attribute changes throughout the process. There consistency or type of links in the manner in which a chain link is joined with the preceding and following it, and the original sample has no central significance. Each link, once included in a complex chain is as important as the first, and can become the magnet that attracts a number of other objects. " (Vygotsky, 1934:52). Also in the same way refers to "... complex is characterized by diffuse flow of each attribute that links the isolated elements. Ties Through fuzzy and indeterminate groups form perceptually concrete objects or pictures." (Vygotsky, 1934:53). This Author complexes between thought and conceptual thinking is thinking pseudo - conceptual.

On the same page 53 Vygotsky says "To complete the complex scheme of thought, we describe a latter type, the bridge, as it were, between the described and the final stage, higher development of concept formation. This type we have given the name of pseudo-concept ... " and continues on page 54 stating "In the experimental environment, the child produces a pseudo-concept increasingly surrounding an example with objects that could well have been assembled on the basis of an abstract concept." In this way it is moving to a conceptual thinking that, however, does not eliminate the complex but thought by this shaping underlying inner speech. "In inner speech, the phenomenon reaches its climax. Not uncommon that egocentric speech be inexplicable to others. Watson says that inner speech be incomprehensible ... " (Vygotsky, 1934: 109)

"But while in external speech thought is embodied in words, in inner speech words die as soon as the thought passed. Inner speech is largely thought of pure meanings, is dynamic and unstable, fluctuating between the word and thought, the two components roughly outlined verbal thought. Their true nature and location can only be understood after examining the next plane of verbal thought, even more internal than inner speech ... That plane is the thought itself "(Vygotsky, 1934: 110). Many of the authors dedicated to intuition () similarly explain, as a process which should take immediate note to keep the ideas expressed.

The main limitation of Vygotsky, the author relates the key elements addressed on intuition, is in it for the students based on their ideas. As seen in this sketch of the fundamental conceptions about intuition is a multifactor process with causes that have not yet been fully clarified scientifically. It also follows the earlier draft which is a process with a high degree of uncertainty involving nonconscious processes. That is why this author believes that it is a process characterized by complexity.

On the other hand several authors recognize the role of affective processes (Pretz, JE, \& Totz, KS, 2007; Pretz, JE, 2008, Dane \& Pratt, 2009; Sinclair, 2011). Recent research on the role of emotions and expertise also suggests that intuition is more contextual than you think (Baylor, 2001; Coget, 2004; Pretz, JE, \& Totz, KS, 2007, Sinclair, 2011) for considering what intuition is necessary to analyze the activity in which the person develops.

Another element to consider is the relationship intuition and subjective processes taking place in the person. For 
(Gonzalez, 2007) subjective sense is defined as the psychological unit developing inseparable integrates symbolic processes and emotions, so that the emergence of one evokes the other, without cause, and without there being any linearity in the subsequent unfolding of these processes, during which new features are appearing new psychological and subjective meanings. The subjective senses are a human production that takes place in the experience, but it takes dynamic forms of organization, both within the personality, providing the basis for a redefinition of the concept, and in different social spaces within which develop different human activities. That is why the author felt intuition can be considered as a process that is part of the subjective sense to develop on the basis of the experience (Pretz, JE, \& Totz, KS, 2007; Pretz, JE, 2008, Dane \& Pratt, 2009; Sinclair, 2011;, Jeffrey G., 2011, Dane, E., \& Pratt, M. G, 2007; Morewedge and Kahneman, 2010; Sinclair and Ashkanasy, 2005, Martin and Hanlon, 2007; DANE and PRATT , 2007; Epstein, 2008; Betsch, 2008; Morewedge and Kahneman, 2010) and adopting dynamic forms.

However, the author does not match Pretz (2011) when he says that there are several types of intuition: inferential and affective holistic because it represents a dichotomy process unnecessarily product cognitivist conception of the author. To the author's intuition manifests depending on the interests and motivations of the individual constitutes an expression of the subjectivity of the individual concept defined by Fernando Gonzalez (2010) in a particular activity, thus manifests itself in different ways.

From the variety of existing criteria and integrating intuition and exposed to the elements the author intuition is the complex process without conscious regulation given to appropriate forms of activity depending on the individual's motivational training and is based on experiences accumulated to form free associations in a particular historical and social context that is integrated in the subjective sense.

Immediate task is proceeding to clarify the relationship between intuition and creativity in computer science. The research of the necessary elements for the consideration of what creative and if a person is creative or not is today under heavy yet controversial, especially on informatics context. The creative process present in people who are dedicated to solving your computer problems or teaching has different characteristics to other sciences as it is permeated by the characteristics of the branch of human knowledge in which it develops. The development of creativity in a computer context it will play in three fundamental aspects expressed by Dr. Carlos Exposito (2009):

1. Protection of Information.

2. Transmission of Information.

3. Conservation of Information.

It is the author's opinion that working with different system and also created one of the edges where the computer expresses creativity, especially when these systems lead to the paradigm shift.

In the definitions of Cuban writers on creativity discussed earlier in this thesis highlights different elements that, in the opinion of the author, must be analyzed in the context of teaching programming or software production.

The author believes that the ultimate in computing refers to can be found in the production process of concepts, methods, models, systems and / or computer algorithms that have been made previously in a given social context. The novelty in this case ranges from software developers, companies that set guidelines for the work computer to the student preparing for the production of software or computer education. However, it is important to note that the process proceeds in different manner for each of the cases mentioned above.

A remarkable element points to the social historical context in which the individual develops as Mitjáns says Dr. Albertina (2002) in the definition discussed above, since it addresses the issue of student and algorithms creator and producer discovered or not software, commercial occasionally, until the scheduler is in software producing companies. In the analysis of creativity in the context of information technology is essential to consider the conditions under which it develops and the resources available to each of them that determines the platform used to develop the systems. Therefore consideration of social demands is an important element to consider in the development of creativity in the context of teaching programming.

While integrity must express the cognitive and the affective, emotional process in the case of information is vital. The motivation for the implementation of activities related to solving computer problems and contradictions they contain, and induces favorable performance of cognitive actions needed to remedy them as expressing the authors Shari Park-Gates (2001), Saturnino de la Torre (2002), Marta Martinez Wheeler (1999) among others. Cognitive activity in informatics is preceded by an intense motivational contradictions arising from problematic situations expressed in the individual drives in the computer building. To the author's creativity in computer science is defined as the process of producing complex concepts, methods, models, systems and / or computer algorithms related to aspects of information technology development to meet the social demands characterized by generation, extension, flexibility and autonomy.

The characteristics listed by America Gonzalez (1999) fit the object of study so it is necessary to resize its dimensions in the computer context that the author may be considered:

Generation: The original production itself, which relates to the resourcefulness and discovery to act independently, to reach creative transformation. Indicators are:

1. Production of various concepts, models, algorithms or codes for the solution of a problem.

2. Determination of the algorithms or concepts to be applied in the solution of a problem.

Extension: This refers to the production of ideas, questions, problematizations, and solutions that advance the knowledge and experience themselves and / or others. It is the author's opinion referred to in computer algorithms to obtain not studied in classes, programs and models that integrate complex data types discussed forming the new data types or problems to solve. Indicators are:

1. Design and development of new systems, concepts, algorithms or codes that solve a problem.

2. Ideas to improve the systems, concepts, or codes existing algorithms to solve a problem.

3. New problems arising from practice that can be computerized. 
Flexibility: This involves the ability to give a variety of responses, modify the ideas and overcome stiffness. Consider the author expressed in the analysis of different data models, algorithms and codes used to represent the problem and determine its solution and its codification. Are indicators:

1. Possible solutions to the problem.

1. Determining the possible solutions to the problem from the computing resources they have available.

2. Observe and change their opinions based on benchmarking against existing in the solution of the problem when necessary.

3. Collaboration with the persons involved in the process of building the software.

Autonomy: To think for ourselves, make our own decisions without belittling other people's judgments. Determine which of the algorithms obtained is the most efficient and which model best represents the relationships contained in the problem. Are indicators:

1. Using their own criteria in determining the algorithms or concepts to be applied in the solution of a problem.

2. Using experience in developing algorithms, codes or systems.

Creativity computing previously defined to express the process of creating a given computer as a key to an individual's personality together with the attention to be given to the creative process.

Defined in computing creativity, intuition in computing should be characterized depending on the activity performed as defined above. That is why the author considers the complex process without conscious regulation that gives the ownership and / or obtaining concepts, methods, models, systems and / or computer algorithms, with the project as a key activity, depending on subjectivity of the individual and is based on experiences accumulated to form free associations in a particular historical and social context. Each of these results of intuition in computer activity must then be verified logically and in this sense, the hardware to use plays an essential role as the ultimate criterion of truth. It is necessary to address this latter approach because, in the opinion of the author, the dialectical hardware - software is contextualized to the concrete historical situation of the computer problem to solve.

Still, in the opinion of this author, has not fully resolved the issues raised on the development of intuition in computing as part of computer creativity if not addressed pathways for development. In commenting above Vygotsky's ideas were discussed important aspects that should not stop being treated. It is the opinion of the author that place individuals in situations that allow solutions with high variability and form associations considering the dialectical relationship between them could be a solution to this problem. Please note also the mistakes and include them as part of learning, assuming that the error is necessary and providing a holistic and comprehensive training to individuals.

On the other hand (Liberman, 2000; Pretz and Totz, 2007, Sinclair, 2011; Sinclair, 2010) suggest the need for expertise and personally experienced obtained with a high degree of emotional involvement to be taken over by the intuitive processes. For these authors the contradictions underpin the development of intuition and in the opinion of a large number of authors teaching problem represents the ultimate opportunity to feed into the process of teaching. It is therefore necessary to characterize the teaching problem in computer education. Within the categorical system of teaching problem highlights the problem situation. The problem situation represents the contradiction resulting in students 'surprise', a state of bewilderment at a situation in which he knows that there is "something" is wrong, it is not right in line with the system of knowledge which is has appropriated.

In the teaching of Computing the author acknowledges that there are several types of problematic situations given by the characteristics of this science as a realization of these general

\section{A. No correspondence between the concept, model or procedure and the requirements of the task}

This situation is in line with the first given by Marta Martinez. The student does not know the concept and / or the procedure that allows solving the task. To solve problems associated with the determination of a value and comparison with previous values is necessary to introduce the concept of settlement. The solution of the problem is given in the array concept as variable type and establishing operations in computing expression.

\section{B. Contradiction between the concept, model and / or} the procedure and its expression in a computer system

The student knows various concepts or models but not how they are managed by a computer system or computer science. In this case we can find concepts like cycle, variable, column, row. The first concept is taught from the construction of the pseudo code is presented in contradiction coding algorithm obtained.

\section{No correlation between the expression of a concept computer in another system in the same family and the system used}

This situation can be found in the students who have prepared in Pascal and go to another programming language like $\mathrm{C}++$ or Java. In this case students are mainly based on the analogy and the system helps to solve the problem. It becomes a problem for those students whose teacher development lets them know what is sought. The computing experience plays a key role.

\section{Contradiction between the potential of the system and the task at hand}

Teaching is typical of systems that are updated versions of others with whom already own or the student already knows. It is in the teaching of new language instructions for the task.

\section{E. Contradiction between the algorithm, the pseudo - code and its implementation in a system}

The contradiction lies in the possibility of algorithmic the process, however, can not encode in a computer system. An example of this is seen in the process of copying texts if they know the procedure to copy files. The contradiction is how to select the texts. It can take from a fragment encoding to any encoding step. 


\section{F. Problem Teacher}

The student has assimilated the contradiction contained in the problem situation and is oriented toward what to look for. The problem must be well developed so that students can provide elements in the search for the unknown, but gives no solution pathways. The computer education has gone through several approaches systematized by Dr. Carlos Expósito (2009) which are given below:

\section{Manual Focus \\ 2. Algorithmic Approach \\ 3. Base Problem Approach \\ 4. Focus Problematics \\ 5. Project Approach}

The project approach proposed by the author proposes to solve the task in which they integrate knowledge based on the core concept is being called by the author as a project with minimum requirements. The solution of the project with minimum requirements for a student involves a set of basic knowledge that should be included in the project to be evaluated. Based on these minimum requirements are structured problematic situations that the author has termed as problematics nodes associated with the project.

The concatenation of problematics nodes and relationships established between them to solve the project is one of the fundamental aspects of the system approach in teaching computer science (54).

The teaching problem is characterized by the formation of the contradiction between the known and the unknown structured by the teacher. In problémico approach integrated with the project approach, the author believes that the contradiction can be structured in two ways substantially different:

- enunciated by the teacher.

- emanating from the solution of the project submitted by the student.

For the student has a higher level of demand since they face several problematic situations (along the theme) different in context to his and the outcome (knowledge) should be reformulated in terms of their problem be solved, an important element in structuring its scope. Another edge of the situation is the approach by the student problems that may lead to the solution of your project, which encourages questioning, for problems that contributes to the development of intuition as part of creativity in computer science.

\section{CONCLUSIONS}

Intuition as part of the creative process is one of the least studied in the literature although there is a resurgence of his analysis in the scientific literature. Various definitions of intuition in the literature is cognitive in nature but does not occur in the same way from the cultural historical approach, main reference of the investigation. Therefore define intuition based on the historical and cultural budgets is a major theoretical result. To be consistent with this relation is then defined psychological intuition in an area of knowledge and how to develop professionals in this area, being the result of fundamental theoretical research.

\section{REFERENCES}

[1] Ashkanasy, W. J. Zerbe, \& C. E. J. Härtel (Eds.), Managing emotions in the workplace:143-163. Armonk: M. E. Sharpe.

[2] Baylor, A. L. 2001. A U- shaped model for the development of intuition by level of expertise. New Ideas in Psychology, 19: 237244. http://dx.doi.org/10.1016/S0732-118X(01)00005-8

[3] Bechara, A. 2004. The role of emotion in decision- making: Evidence from neurological patients with orbitofrontal damage. Brain and Cognition, 55: 30-40. http://dx.doi.org/10.1016/j.bandc. 2003.04.001

[4] Behling, O., \& Eckel, N. L. 1991. Making sense out of intuition. Academy of Management Executive, 5(1): 46-54.

[5] Cheltenham, UK and Northampton, MA, USA: Edward Elgar.Slovic, P., Finucane, M., Peters, E., \& MacGregor, D. G. 2002. The af ect heuristic. In T. Gilovich, D. Grii n, \& D. Kahneman (Eds.), Heuristics and biases: The psychology of intuitive judgment: 397-420. New York: Cambridge University Press.

[6] Coget, J. F. 2004. Leadership in motion: An investigation into the psychological processes that drive behavior when leaders respond to 'real- time' operational challenges. Doctoral dissertation. Anderson School of Management, UCLA.

[7] Crossan, M. M., Lane, H., \& White, R. E. 1999. An organizational learning framework: From intuition to institution. Academy of Management Review, 24(3): 522-537.

[8] Damasio, A. R. 1994. Descartes' error: Emotion, reason and the human brain. New York: HarperCollins.

[9] Damasio, A. R. 1999. The feeling of what happens: Body, emotion and the making of consciousness. London: Vintage.

[10] Dane, E. 2010. Reconsidering the trade- of between expertise and lexibility: A cognitive entrenchment perspective. Academy of Management Review, 35: 579-603. http://dx.doi.org/10.5465/ AMR.2010.53502832

[11] Dane, E., \& Pratt, M. G. 2009. Conceptualizing and measuring intuition: A review of recent trends. International Review of Industrial and Organizational Psychology, 24: 1-40.

[12] DANE, ERIK and PRATT, MICHAEL G. (2007). Exploring intuition and its role in managerial decision making. Academy of Management Review. Vol. 32, No. 1, 33-54. http://dx.doi.org/10.5465/AMR.2007.23463682

[13] de la Torre, Saturnino. Creatividad en la reforma española. En http://educacion.jalisco.gob.mx/consulta/educar/10/10saturn.html. 2002.

[14] De Prado, David (2003). Enseñanza y aprendizaje (e/a) Creativoinventivos. En http://www.iacat.com/webcientifica/EDUCREAIV.PDF. De Prado, David(2003). La creatividad expresiva integral: Talentos. En URL:http://www.iacat.com/Expresarte.htm.

[15] De Prado, David(2003). Creatividad para transformar sustancialmente la curriculares: una estrategia. En http://www.iacat.com/ webcientifica/educrea\%20capitulo\%20V.pdf.

[16] De Prado, M.V (1995). "Experiencias y conceptos matemáticos, 7. EGB". Editorial Luis Vives, España.

[17] Dijksterhuis, A. 2004. Think dif erent: The merits of unconscious thought in preference development and decision making. Journal of Personality and Social Psychology, 87: 586-598. http://dx.doi.org/10.1037/0022-3514.87.5.586

[18] Dijksterhuis, A., \& Aarts, H. 2010. Goals, attention, and (un)consciousness. Annual Review of Psychology, 61: 467-490. http://dx.doi.org/10.1146/annurev.psych.093008.100445

[19] Dörler, V. 2010. Creative intuition. Manuscript in preparation. Strathclyde University, Glasgow.

[20] Duggan, W. 2007. Strategic intuition. New York: Columbia Business School Publishing.

[21] Epstein, S. 1990. Cognitive-experiential self- theory. In L. Pervin (Ed.), Handbook of personality theory and research: 165-192. New York: Guilford Press.

[22] Evans, J. St. B. T. 2007. Hypothetical thinking: Dual processes in reasoning and judgment. Hove, UK: Psychology Press.

[23] Éxpósito Ricardo, Carlos. Elementos de metodología de la enseñanza de la informática. Editorial Pueblo y Educación. Cuba. 2009. 
[24] Forgas, J. P. 1995. Mood and judgment: The Af ect Infusion Model (AIM). Psychological Bulletin, 117: 39-66. http://dx.doi.org/ 10.1037/0033-2909.117.1.39

[25] Goldberg, P. 1983. The intuitive edge: Understanding and developing intuition. Los Angeles: Jeremy P. Tarcher.

[26] González Rey, Fernando. Las categorías de sentido, sentido personal y sentido subjetivo en una perspectiva histórico-cultural: un camino hacia una nueva definición de subjetividad. Universitas Psychologica, Vol. 9, Núm. 1, enero-abril, 2010, pp. 241-253

[27] González Valdés, América(1990). Cómo propiciar la creatividad. Editorial Ciencias Sociales, La Habana.

[28] González Valdés, América(1995). "Prycrea: pensamiento reflexivo y creatividad". Editorial Academia. La Habana.

[29] González Valdés, América(1999). Conceptualización de la creatividad en PRYCREA. http://www.clacso.edu.ar/ libros/ cuba/gonza2.rtf.

[30] Hammond, K. R., Hamm, R. M., Grassia, J., \& Pearson, T. 1987. Direct comparison of the efficacy of intuitive and analytical cognition in expert judgment, IEEE Transactions on Systems, Man, and Cybernetics, 17(5): 753-770.

[31] Hayashi, A. M. 2001. When to trust your gut. Harvard Business Review, 79: 59-65.

[32] Hill, O. W. 1987. Intuition: Inferential heuristic or epistemic mode? Imagination, Cognition, and Personality, 7(2): 137-154. http://dx.doi.org/10.2190/2L9K-57WM-M917-6FWN

[33] Intuition from the Perspective of Cognitive-Experiential SelfTheory. Seymour Epstein. In: Intuition in judgment and decision making. Library of Congress Cataloging-in-Publication Data. New York USA. 2008. pp. 3-22.

[34] Kahneman, D., \& Klein, G. 2009. Conditions for intuitive expertise: A failure to disagree. American Psychologist, 64: 515-526. http://dx.doi.org/10.1037/a0016755

[35] Klein, G. 1998. Sources of power: How people make decisions. Cambridge, MA: MIT Press.

[36] Klein, G. 2003. Intuition at work. New York: Doubleday.

[37] Martínez Llantada, Marta (1980). La enseñanza problémica de la filosofía marxista leninista. Editorial Ciencias Sociales. La Habana.

[38] Martínez Llantada, Marta (1995). "Calidad educacional, actividad pedagógica y creatividad” Editorial Academia. La Habana.

[39] Martínez Llantada, Marta(1999). El desarrollo de la creatividad mediante la enseñanza problémica en la actualidad. Teoría y práctica. Curso 6 Pedagogía 1999. La Habana.

[40] Martínez Mígueles, Miguel (2003). El Proceso Creador a la Luz de la Neurociencia. En http://prof.usb.ve/miguelm/proceso creador.html.

[41] MASLQW, A. H (1968). Towards a Psychology of Being. Litton, New York.

[42] Mintzberg, H., Ahlstrand, B., \& Lampel, J. 1998. Strategy safari: A guided tour through the wilds of strategic management. New York: Free Press.

[43] Mitjáns Martínez, Albertina. Creatividad, personalidad y su educación. Editorial Academia. La Habana 1995

[44] Mitjáns Martínez, Albertina. Cómo desarrollar la creatividad en la escuela. En: http://cte.ilce.edu.mx/diplomado/plan de estudios/ modulo1/lectura apoyo 1b.htm. 2002.

[45] Mitjáns Martínez, Albertina(1995). Creatividad, personalidad y su educación. Editorial Academia. La Habana.

[46] Mitjáns Martínez, Albertina(1997). Estrategia, Métodos y Programas. en Pensar y crear educar para el cambio. Editorial Academia. La Habana.

[47] Mitjáns Martínez, Albertina(1997). Programas, técnicas y estrategias para enseñar a pensar y crear. Un enfoque personológico para su estudio y comprensión en Pensar y crear educar para el cambio. Editorial Academia. La Habana.

[48] Mitjáns Martínez, Albertina(2002). Los estudios sobre la creatividad en Cuba: actualidad y perspectivas. En http://educacion.jalisco.gob.mx/consulta/educar/10/10albert.html..

[49] Monsay, E. H. 1997. Intuition in the development of scientii c theory and practice. In R. Davis- Floyd, \& P. S. Arvidson (Eds.), Intuition: The inside story: 103-120. New York: Routledge.
[50] Morewedge, Carey K. and Kahneman, Daniel (2010). Associative processes in intuitive judgment. Trends in Cognitive Sciences, October 2010, Vol. 14, No. 10 http://dx.doi.org/10.1016/ j.tics.2010.07.004

[51] Osbeck, L. M. 2001. Direct apprehension and social construction: Revisiting the concept of intuition. Journal of Theoretical and Philosophical Psychology, 21(2): 118-131. http://dx.doi.org/ 10.1037/h0091201

[52] Pacini, R., \& Epstein, S. 1999. The relation of rational and experiential information processing styles to personality, basic beliefs, and the ratio- bias phenomenon. Journal of Personality and Social Psychology, 76: 972-987. http://dx.doi.org/10.1037/00223514.76.6.972

[53] Pretz, J. E., \& Totz, K. S. 2007. Measuring individual dif erences in af ective, heuristic, and holistic intuition. Personality and Individual Differences, 43: 1247-1257. http://dx.doi.org/10.1016/ j.paid.2007.03.015

[54] Referenciado en: Pérez Viera, Odalys (2001): La creatividad en el proceso pedagógico profesional. Conferencia Magistral. Encuentro Cuba - Argentina. Cojímar. La Habana. Pág. 8

[55] Referenciado en:Grover, Nicola(1999)Psychoanalytic Aestheticcs. Chapter I: Freud's theory of Art and Creativity. . En http://www.human-nature/free-associations/glober.html

[56] Referenciado por: González Suárez, Enrique. Desarrollo de la creatividad en la formación de los profesionales.. En: http://www.infomed.sld.cu/revistas/aci/vol9 1 01/aci031001.pdf. 2002

[57] Reimann, M., \& Bechara, A. 2010. The somatic marker framework as a neurological theory of decision- making: Review, conceptual comparisons, and future neuroeconomics research. Journal of Economic Psychology, 31(5): 767-776. http://dx.doi.org/ 10.1016/j.joep.2010.03.002

[58] Rory Martin, Philomena Hanlon (2007). An Examination of the Role of Intuition in Individual Decision Making in Organisations. Eircom Broadband. Conference paper. Dublin Institute of Technology.

[59] Seligman, M. E. P., \& Kahana, M. 2009. Unpacking intuition: A conjecture. Perspectives on Psychological Science, 4(4): 399-402. http://dx.doi.org/10.1111/j.1745-6924.2009.01145.x

[60] Simon, H. A. 1987. Making management decisions: The role of intuition and emotion. Academy of Management Executive, February: $57-64$.

[61] Sinclair and Ashkanasy(2005). Intuition : Myth or a Decisionmaking Tool? Marta Sinclair and Neal M. Ashkanasy. Management Learning \#36: 353 http://dx.doi.org/10.1177/1350507 605055351

[62] Sinclair, M. 2010. Misconceptions about intuition. Psychological Inquiry, 21: 1-9. http://dx.doi.org/10.1080/1047840X.2010. $\underline{523874}$

[63] Sinclair, M. 2011. Intuitive proi le of i lm makers. Paper presented at the Academy of Management annual meeting, San Antonio, TX, August, 12-16.

[64] Sinclair, M., \& Ashkanasy, N. M. 2005. Intuition: Myth or a decision- making tool. Management Learning, 36(3): 353-370. http://dx.doi.org/10.1177/1350507605055351

[65] Sinclair, M., Ashkanasy, N. M., \& Chattopadhyay, P. 2010. Af ective antecedents of intuitive decision making. Journal of Management and Organization, 1: 382-398. http://dx.doi.org/10.5172/jmo.16.3.382

[66] Sinclair, M., Ashkanasy, N. M., Chattopadhyay, P., \& Boyle, M. V. 2002. Determinants of intuitive decision- making in management: The moderating role of af ect. In N. M.

[67] Sinclair, M., Sadler- Smith, E., \& Hodgkinson, G. P. 2009. The role of intuition in strategic decision making. In L. Costanzo \& R. B. McKay (Eds.), The handbook of research on strategy and foresight: 393-417.

[68] Stanovich, K. E., \& West, R. F. 2000. Individual dif erences in reasoning: Implications for the rationality debate? Behavioral and Brain Sciences, 23: 645-65. http://dx.doi.org/10.1017/ S0140525X00003435

[69] Vaughan, F. E. 1979. Awakening intuition. New York: Doubleday. 
[70] Vygotsky, L.S. Pensamiento y lenguaje, . Teoría del desarrollo cultural de las funciones psíquicas, Ediciones Fausto, Argentina. 1995

\section{AUTHOR}

Walfredo González Hernández. Graduate degree in education specialty of mathematics and informatics. Master on Didactic mention Mathematics educations and $\mathrm{PhD}$ of Pedagogical Sciences. Coordinates the Laboratories of Technologies in Educations of University of Matanzas. Has published over 15 papers in refereed journals.

Submitted 25 February 2013. Published as re-submitted by the author 26 June 2013. 